\title{
The Behavior of Noon Saakinah and Tanween in Qur'anic Recitation: In the Light of Generative Phonology
}

\author{
Hamid Ibrahim Al-Shishtawi \\ University of Jordan
}

\begin{abstract}
The present study attempts to apply the rules of the generative phonological theory to the rules of the phonological system of the Qur'anic phonology(science of Tajweed).It focuses on the behavior of the Noon Sakinah and Tanween in the light of generative phonological theory. To do so the paper attempts to generate generative phonological rules for the Qur'anic phonological rules of the Noon Sakinah as a written letter or as a Tanween on the final position of a word. Chomsky's and Halle's generative rules were followed to formulate the rules. Since the paper is related to the phonological rules of the Holy Quran, the data were examples quoted from the Holy Quran.The paper concluded that the generative phonological rules apply to the Quranic phonological rules, but in the case of concealment it is applied partially due to the nature of this rule, its neither assimilation nor complete change and easier than clear pronouncing
\end{abstract}

Keywords: Qur'anic Phonology, Noon sakinah, Tanween, Noon sakinah rules in generative phonology.

\section{Introduction}

A language is a set of signals by which we communicate and express thoughts and emotions . There are a number of general points that are worth mentioning about languages. First, human language is not only a vocal system of communication can be expressed in writing with the result that it is not limited in time or space. Second, no two languages behave in exactly the same way, thus each language has its own set of rules .However, languages share some linguistic components: semantics, syntax, morphology, phonology ,and phonetics yet each one of these components is different from the component of this or that language.

Generative grammar is an approach that developed by Noam Chomsky. It is a linguistic theory that regards grammar as a system of rules generates those combinations of words in a given language. Generative phonology is a component of generative grammar that assigns the phonetic representations to utterances in such way as to reflect a native speaker's internalized grammar. It aims to provide a foundation in the theory of distinctive features.

Generative phonology provides different levels of phonological representation: An underlying representation is the most basic form of a word before any phonological rules have been applied to it. Underlying representations show what a native speaker knows about the abstract underlying phonology of the language. A phonetic representation is the form of a word that is spoken and heard. Phonological rules map underlying representations onto phonological representations. They delete, insert, change segments, or change the features of segments.

Distinctive features to make it possible to capture the generalities of phonological rules. Kenstowicz and Kisseberth(1979:131,132) state that in any given language only certain features of pronunciation are distinctive-that is, unpredictable and thus capable of distinguishing between lexical items in underlying representation. The remaining features are non-distinctive -that is ,predictable and thus incapable of distinguishing one underlying form from another.

Arabic language is the language of the Quran. It is considered the first source of the standard Arabic. The researcher attempts to apply the theory of distinctive features to the rules of the Qura'nic phonology .So, the examples of this paper are going to be from the Qur'an to describe some of the Qur'anic phonological rules which talking about the articulation of the final silent [n॰], "Annoon Assakina", and the "Tanween" both of which are equivalent to the English alveolar nasal /n/. Four main topics are going to be discussed in details in this study, these topics are Idgham, Iqlab, Idhar, and Ikhfaa. Cited in Alduais(2012) Kenstowics(1979, p.2). Introduces generative phonology as a branch of the general theory of transformational generative grammar.

He maintains, "Generative phonology is a subfield of the general theory of language known as generative grammar", He continues, "the ultimate goal of linguists working within this framework is to answer the question: what is the nature of language?" (ibid, p.2).

Kenstowics, stresses on the importance of the generative phonological rules as a tool of systematizing a particular language in particular and all languages in a framework of ruled system in general, (ibid, pp. 25-43). 


\section{Definitions:}

Czerepinski(2000,23) defines Tajweed as the following: Tajweed: the linguistic definition of it is Betterment Applied definition: Articulating every letter from its articulation point and giving the letter its rights and dues of characteristic. Rights of the letter are its required characteristics that never leave it. The dues of the letter are it presented characteristics that are present in its one of the time, and not present at other times i.e. Idgham (iped,40)Czerepinski also defines Noon saakinh and tanween .The noon sakinah is a noon $/ \mathrm{n} /$ free from any vowel (haraka).It remained unchanged in its written form as well as in pronunciation when continuing to read after it and when stopping on it.Noonsakinah occurs in nouns and verbs in the middle of the word and at the end of the word, and occurs in prepositions and particles only at the end of the word. The tanween is a term for an extra noon saakinah not used for emphasis, found at the end of nouns when continuing reading, but absent from the noun in the written form and abandoned in pronunciation when stopping.(the noon of the tanween is pronounced but not written). Tanween has three different shapes, each of these shapes consists of one of the short vowels : [a], [u], [i] and the final silent [n] shown as follows:

\begin{tabular}{|l|l|l|}
\hline $\begin{array}{l}\text { The Arabic shapes of } \\
\text { Tanween }\end{array}$ & Pronounced as & Examples \\
\hline$(")$ & un & ['azi:zun] \\
\hline$($ s) & an & ['azi:zan ] \\
\hline$($ ) $)$ & in & [ ${ }^{\mathbf{c} a z i: z i n]}$ \\
\hline
\end{tabular}

Idgham in its general sense, covers most of the assimilation processes. However, it is not an equivalent term exactly to English "assimilation' 'The closest Arabic term to this is taqarub- al aswat . Alfozan(1989,58).

Assimilation is merging one sound of certain letter into the other. According to Alfozan(1989,61)to sum up what the term idgham means in classical Arabic, it may refer to any one of the following: Germination Assimilation of final / n/ to the six sounds(w,y,r,l,n,m)Complete assimilation Partial assimilation.

\section{Literature review}

There are tens of papers on the Qura'nic phonology in the light of generative phonology concluded different results. Alfozan (1989) analyzed the nasal phonological processes in Qura'nic recitation and standard Arabic using the distinctive features theory which developed by Chomsky and Halle (1968).He argued that sonorants induce different types of nasal assimilation: complete regressive assimilation of / $\mathrm{n} /$ to liquid and nasals Partial regressive assimilation to glides. He states that coronal nasal loses place of articulation if the following consonant is bilabial nasal and the glides /w,y/ behave like other obstruent's ,except gutturals and bilabials. Alduais (2012) using the Chomsky's and Halle's book to formulate the generative phonological rules for the Qura'nic phonological rules non syllabic Noon's rules. He concludes that generative phonology theory does apply on the qura'nic phonological rules but partially . He added that it is not fair to say that generative phonology is not applicable for may be the nature of this research was not applied and conducted in the way that can make generative phonology suit the rules of concealment where in the phonetic representation requires to order compound features. Al-Hashmi(2001) analyzed the four patterns of Tajweed, the phonology of Tajweed, she argued that the phonological patterns of Tajweed are also- by large- found in the different dialects of Arabic like Sudanese Arabic and even some of the Semitic languages and dialects. Nonetheless, the whole set of the nearly twenty-eight patterns comprising Tajweed is collectively used only when reciting the Holy Qur'an or when performing the five daily prayers and twenty-eight sounds distributed among the four patterns of nasal $\mathrm{n}$ assimilation are grouped into the three natural sound classes of sonorants, obstruent's and gutturals. Obied (2016) concluded that phonological rule is a method for describing the way in which individual sounds are produced in spoken languages and these rules are written out in a specialized notation that codifies the way in which a sound or group of sounds is altered by appearing in a specific linguistic context. Phonological rules vary between languages and dialects, and they reflect the common pronunciation habits of various linguistic groups.

\section{Theoretical background}

Katamba,(1989) suggests that sounds can be thought of as bundles of distinctive features; they are the result of more or less simultaneous articulators activities of various organs which merge with each other. He argued that distinctive feature theory claims that there is a universal inventory of phonological construction materials from which various languages chose different elements which they use in building their phonological systems. "John Golden Smith (1995) defines phonological rules as mappings between two different levels of sound representation in this case, the abstract or underlying level and the surface level. Bruce Hayes (2009) describes them as "generalizations" about the different ways a sound can be pronounced in different environments. 
That is to say, phonological rules describe how a speaker goes from the abstract representation stored in their brain, to the actual sound they articulate when they speak. In general, phonological rules start with the phoneme that is stored in the speaker's mind and yield the final form, or what the speaker actually pronounces."

Chomsky and Halle(1968) suggested that representations are mentally constructed by the speaker and the hearer and underlie their actual performance in speaking and" understanding." They suggested , moreover, that each formative of the surface structure can also be represented as a feature matrix, they proposed also that the formative structure is much more abstract, however; its 'relation to the speech signal is not as direct as that of the phonetic representation and proposed that the rules of the phonological component have a fixed form and a specific organization, that they apply in a fixed manner determined by the labeled bracketing of the surface structure and that they meet various additional conditions depending on their formal relations.

Quoted from Abalkheel(2016) Arabic is the liturgical language of Islam since the Quranic composed of it. In Quranic recitation, noon sakinah and nunation undergo different processes within and across words boundaries, depending on the following sound. Ibn Al-Jazari (1927) stated that there are some slight differences in the characteristics of nasal assimilation between the ten qiraa'aat (i.e., Quranic readings), such as retaining the nasality of $/ \mathrm{n} / \mathrm{when}$ it assimilates to a following liquid. This paper focuses on Hafs $\mathrm{an}$ Asim reading because it is used by the vast majority of Muslims and because it is the nearest reading to Classical Arabic (Noldeke, Schwally\& Bergstrasse, 2013).

According to Katamba, phonology is the branch of linguistics, which investigates the ways in which sounds are used systematically in different languages to form words and utterances. Thus, each language has some sounds, which are not available in the other languages .Since the Holy Quran was revealed in Arabic language it is required for us to know the recitation rules and the correct way of the articulation of the sounds. Arabic language has the phonological system that is not available in other languages it is the phonology of Qur'an (the science of Tajweed)that refers to the rules governing pronunciation during recitation of the Qur'an, the term Tajweed is derived from the root $\mathrm{j}-\mathrm{w}-\mathrm{d}$ meaning, " to make well" make better. Learning Tajweed of the recitation of the Qur'an is necessary matter, for by it one can distinguish the correct pronunciation from that which is not .Dr. Ayman Sawyd in Czerepinski(2000) .

\section{Discussion and results}

Al-fozan, Abdurrahman, (1989,50). progressive assimilation happens when one consonant becomes like the preceding consonant, it becomes similar to it carrying some of its features like the feature of voicing.

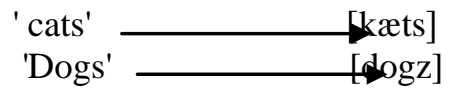

Regressive assimilation occurs when the final consonant changes to become like the initial consonant of the second word, for example:

$\begin{array}{rr}\text { 'sit down' } & \text { [siddaun } \\ \text { 'That person' } & \text { [ðæpərsən] }\end{array}$

When talking about the Arabic language, it is found that some assimilation processes are similar to the English ones, and some are different specially those occur while reciting the Qur'anic verses. The main processes known in "Attajweed science" (the phonology of the Qur'an) as, "Idgham", "Iqlab" and "Ikhfaa Annoon Assakina( the silent) [n]The consonant [n] whose sound is affected and changed when it occurs as a silent $/ \mathrm{n} /$ in the final position of the last syllable of a word whether a noun, a verb or a preposition. It doesn't have any harakat: " fatha, kasra or dhamma" , the short vowels [a], [i], [u].

The tanween is a term for an extra noon saakinah not used for emphasis, found at the end of nouns when continuing reading, but absent from the noun in the written form and abandoned in pronunciation when stopping.(the noon of the tanween is pronounced but not written). Assimilation processes: Idgham in Arabic means the merging of the sound of the silent [nं] or 'tanween' which is also pronounced as [in, un, an] whenever it occurs in final position and is followed by one of these six sounds: $/ \mathrm{m} /, / \mathrm{n} /, / \mathrm{y} /, / \mathrm{w} /, / \mathrm{r} /$, and $/ 1 /$. As a result, these sounds will be geminated and written as one letter with [shaddah] (doubling marker) above it. Idgham is classified differently by Arab scientists and phoneticians depending on the way and the degree of assimilation. Considering how it takes place, two types of assimilation are recognized: with nasalization (incomplete) and without nasalization (complete). Idgham with nasalization(incomplete assimilation): This kind of assimilation takes place when any one of the following four sounds $[\mathrm{y}, \mathrm{n}, \mathrm{m}, \mathrm{w}]$ comes at the beginning of the word which is preceded by a final silent/n/ or 'attanween'.

\begin{tabular}{|l|l|}
\hline man yaqu:lu & [ mayyaqu:lu] \\
\hline
\end{tabular}

Idgham without nasalization(complete assimilation) 
This process occurs when the sound $/ \mathrm{n} /$ is followed by the sound $/ \mathrm{l} /$ or the sound $/ \mathrm{r} /$ as an initial sound in another word. In such a case, /n/ will disappear completely and no nasalization will take place, the [ $\mathrm{n}$ ] changes completely into [ 1] and it changes completely into $[\mathrm{r}]$ then these sounds $(/ \mathrm{l} /, / \mathrm{r} /)$ will be geminated but without nasalization.

$$
\begin{array}{|l|l|}
\hline \text { min ladunni } & \text { [milladunna] } \\
\hline
\end{array}
$$

Iqlab'Iqlab' means that the three nasal sounds of 'attanween'; /an/, /un/, or /in/, in addition to the silent $/ \mathrm{n} /$ will be changed to the nasal bilabial $/ \mathrm{m} /$ whenever these sounds are followed by the bilabial stop $/ \mathrm{b} / \mathrm{in}$ a word-initial position (in two words) or in one word.

Ikhfaa

\begin{tabular}{|l|l|}
\hline Min $b a^{c} d$ & {$\left[\right.$ Mimba $\left.^{c} d\right]$} \\
\hline
\end{tabular}

Wherever the nasal sounds, the silent [n] or 'attanween' is followed by one of the following sounds (f, $\Theta, \partial, d, t, d, t, \partial$, $\mathrm{s}, \mathrm{s}, \mathrm{z}, \breve{s}, \mathrm{j}, \mathrm{k}, \mathrm{q}$ ), assimilation should take place. The sound [n] changes its place of articulation , but it keeps the quality of nasalization, the process of assimilation of this kind is called "Ikhfaa".

\begin{tabular}{|c|c|c|c|}
\hline Sound features & Sound & Transcription of the written text & Transcription of articulation \\
\hline Labio-dental & $\mathrm{f}$ & al-ªnfal & {$\left[\mathrm{al}-{ }^{\circ} \mathrm{a} \sim \mathrm{fal}\right]$} \\
\hline \multirow{3}{*}{ Inter-dental } & $\theta$ & manӨuran & [ma Ouran] \\
\hline & ð & munðir & [mu dir] \\
\hline & ð & 'inðuru & ['i ðuru] \\
\hline \multirow[t]{7}{*}{ alveolar } & $\mathrm{t}$ & 'antum & {$\left[{ }^{\mathrm{a} a}\right.$ tum $]$} \\
\hline & $\mathrm{d} \cdot$ & 'andada & ['a dada $]$ \\
\hline & $\underline{t}$ & yanțiqu:n & [ya tiqu:n] \\
\hline & $\mathrm{s}$ & 'al-’insan & [ ${ }^{3}$ al- $\left.{ }^{0} \mathrm{i} \sim \operatorname{san}\right]$ \\
\hline & $\underline{s}$ & min șilșal & [mi șilșal] \\
\hline & $\mathrm{Z}$ & 'anzala & {$\left[{ }^{\circ} \mathrm{a} \sim\right.$ zala $]$} \\
\hline & $\underline{d}$ & manḍd & [ma dud] \\
\hline Alveo-palatal & $\check{\mathrm{s}}$ & manšura & {$[$ ma šura $]$} \\
\hline palatal & $\mathrm{j}$ & `anjaynakum & [ª jaynakum] \\
\hline Velur & $\mathrm{k}$ & minkum & [mi kum] \\
\hline Uveolar & $q$ & man qala & [ma qala] \\
\hline
\end{tabular}

from these examples, the nasal sound of the silent $[\mathrm{n}]$ and " attanween" , is hidden but the quality of nasalization strongly dominate the place of articulation of the [n]. this nasalization is called (Ghonnah) according to the (Tajweed scientists). Ithhar .Its linguistic definition: clear or obvious. Its applied definition: pronouncing every letter from its articulation point without a ghunnah on the clear letter.there are six sounds which, when one of them follow a noon sakinah or tanween, causes the noon to be said clearly/?, h, x, $\hbar, \gamma, \mathrm{S}$

\section{Table of Arabic sounds and their Phonetic symbols and transliteration}

\begin{tabular}{|c|c|c|c|c|}
\hline J & ذذ & حد & $\dot{\check{\tau}}$ & $\tau$ \\
\hline$=1$ & ذات & دآ & خَ & $=L$ \\
\hline$r \bar{a}^{2}$ & dâà & dāl & bāa & hà \\
\hline$r$ & d & d & $\mathbf{b}$ & h \\
\hline$[r \sim r]$ & [ة] & [d] & {$[\mathrm{x} \sim x]$} & {$[\mathrm{t}]$} \\
\hline فــ & है & $\varepsilon$ & 5 & I \\
\hline فاء & غيت & عين & ظلاء & $=U$ \\
\hline$f \bar{a}^{2}$ & gayn & cayn & $z \overline{\mathbf{a}}^{2}$ & $t \bar{a}^{2}$ \\
\hline$f$ & $\dot{\mathbf{g}}$ & & $z$ & $\underline{\underline{t}}$ \\
\hline$[\mathrm{f}]$ & {$[\mathrm{Y} \sim \mathrm{B}]$} & [F] & {$\left[\partial^{\mathrm{s}}\right]$} & {$\left[t^{\mathrm{s}}\right]$} \\
\hline & 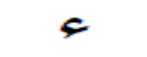 & يب & 9 & \\
\hline & همزة & يباء & و او & $=L$ \\
\hline & hamza & yā' & wāw & hà \\
\hline & & $y$ & $w$ & - \\
\hline & & [j] & {$[w]$} & $\lceil\mathbf{h}$ \\
\hline
\end{tabular}

\begin{tabular}{|c|c|c|}
\hline$=$ & *- & 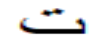 \\
\hline جيح & تاء & تاء \\
\hline ğīm & $\underline{t} \bar{a}^{2}$ & $t \bar{a}^{2}$ \\
\hline ğ & $\underline{\mathbf{t}}$ & t \\
\hline [b] & {$[\theta]$} & {$[t]$} \\
\hline & مـر & ثتث \\
\hline صــــاد & صــاد & شين \\
\hline dāad & șād & šīn \\
\hline d & $s$ & š \\
\hline$\left[d^{\mathrm{s}}\right]$ & {$\left[\mathrm{s}^{\mathrm{s}}\right]$} & {$[S]$} \\
\hline$\dot{ن}$ & ح & U \\
\hline نوتِ & ميّ & Iâm \\
\hline$n$ & $\mathrm{~m}$ & 1 \\
\hline$[\mathbf{n}]$ & {$[\mathrm{m}]$} & {$[1 \sim 1]$} \\
\hline
\end{tabular}

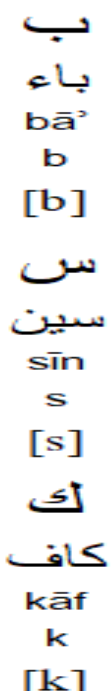

$[\mathrm{k}]$
1

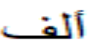

'alif

(a)

[?]

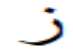

زاي

zāy

$z$

[z]

苞

قافت

qāf

q

[q] 
-nasal

-nasal

6./n/ sound is followed by /1/ sound .It assimilates fully to it .full assimilation without Ghunna(nasalization)

Min ladun

-syllabic
+consonanta
+voiced
+alveolar
+nasal

miladun

-syllabic

+consonantal

+voiced

+alveolar

+lateral

-nasal

-syllabic
+consonantal
+voiced \#
+alveolar
+lateral
-nasal

Exceptions: 1. If the /n/ saakinah and these sounds / j,n,m,o/ were in one word we do not do assimilation (Idgham),it does not work in this case : صنوان ,قنوان , الدنيا ,بنين

2. In these two cases assimilation(Idgham) cannot be applied/ يس و القران , / ن, و القلم وما يسطرون these are separated sounds /ya'+si:n/ نthere is a /n/ saakinah but ,Idgham cannot be applied .Clearness (Ithhar)applies

The second rule :The complete change (Iqlab)

In this case only, the $/ \mathrm{n} /$ sound changes completely to the $/ \mathrm{m} /$ sound if it is followed by the /ب/sound .This rule does not apply elsewhere

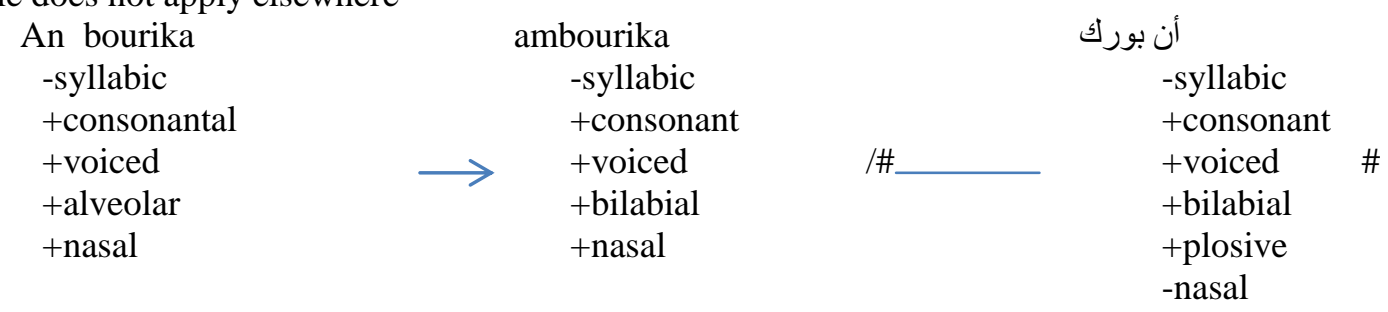

\section{The third rule}

Concealment (Ikhfaa'): in this rule /n/ saakinah is concealed if it followed by one of these sounds:/, ð, $\theta, \mathrm{k}, \mathrm{d}\}, \int, \mathrm{q}, \mathrm{s}, \mathrm{z}$, $\mathrm{f}, \mathrm{t}, \mathrm{d}, \mathrm{t}, \mathrm{d}, \not t, \mathrm{~s} /$. This rule does not apply if /n/ sound followed by any sound other than these sounds

In this rule the tip of the tongue does not touch the plate completely, thus the production of the sound is between nasal/ n/and liquid /l/'in between'. It is neither assimilation nor complete change and easier than clear pronunciation. In other words it is to move the tongue from the $/ \mathrm{n} /$ sound point of articulation to the point of articulation of the sound which follows it directly, with hanging of the body of the tongue between the two points of articulation, with two harakt (two seconds) lengthen .

1. Here the $/ \mathrm{n} /$ sound (as a tanween under the final /s/ ) is followed by /ð/ sound, so /n/ is concealed with light nasalization to move to the /ð/ point of articulation directly

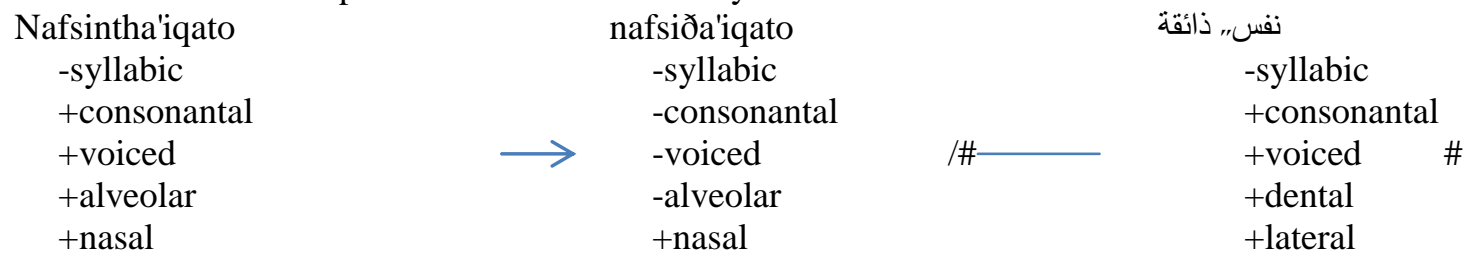

2. Here /n/ sound (as a tanween under the final $/ ت /$ sound ) is followed by/ $/$ /sound ,so it is concealed , with light nasalization to move to the point of articulation of $/ \theta /$ sound directly



3. Here the sound / $\mathrm{n} /$ is followed by the sound / $\mathrm{k} /$, so it concealed ,with light nasalization to move to the point of articulation of the sound / k/.

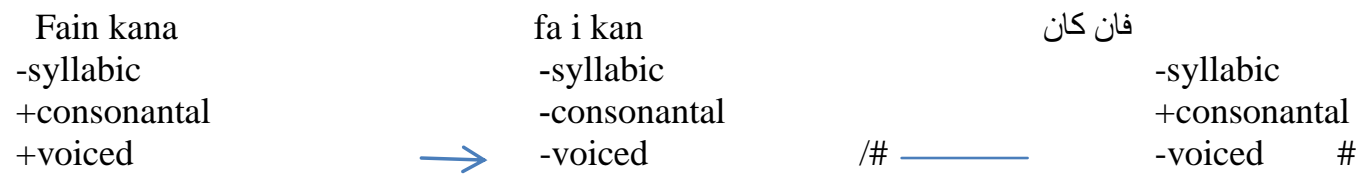




$$
\begin{array}{lll}
\text { +alveolar } & \text {-alveolar } & + \text { velar } \\
\text { +nasal } & \text { +nasal } & + \text { plosive }
\end{array}
$$

4.Here $/ \mathrm{n} /$ sound(as a tanween on the ( alif) is followed by $/ \int /$ sound ,so it concealed with a light nasalization



5.Here $/ \mathrm{n} /$ sound is followed by the sound /q/ so it is concealed with a light nasalization to move to the point of articulation of the sound / q/ (ق)

\begin{tabular}{lccc} 
Wamanqutil & wamqutil & \multicolumn{2}{c}{} \\
-syllabic & -syllabic & -syllabic \\
+consonantal & +consonantal & +consonantal \\
+voiced & -voiced & /\# & -voiced \# \\
+alveolar & -alveolar & & +uvular \\
+nasal & +nasal & +plosive
\end{tabular}

6. Here the $/ \mathrm{n} /$ sound is followed by $/ \mathrm{s} /$ sound it is concealed with a light nasalization to move to the point of articulation of the /s/ sound directly

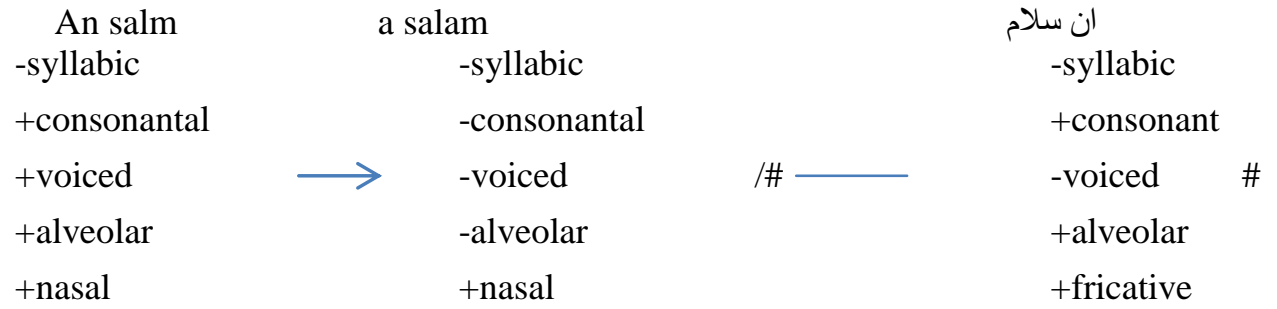

7. Here $/ \mathrm{n} /$ sound is followed by / $\mathrm{d} /$ sound it is concealed with a light nasalization

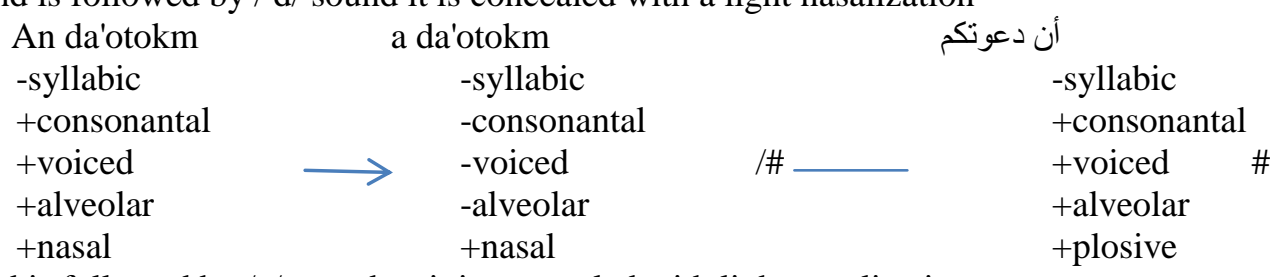

8 .Here $/ \mathrm{n} /$ sound is followed by $/ \mathrm{z} /$ sound so it is concealed with light nasalization

To move to the point particulation of the /z/ sound

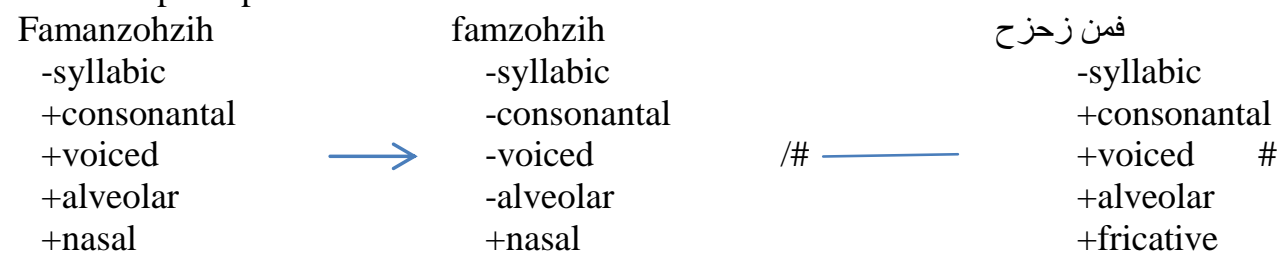

9.Here the /n/ sound (as a tanween under the final $\ddot{a}$ )is followed by /f/ sound so it is concealed with light nasalization to move to the point of articulation of the /f/ sound directly

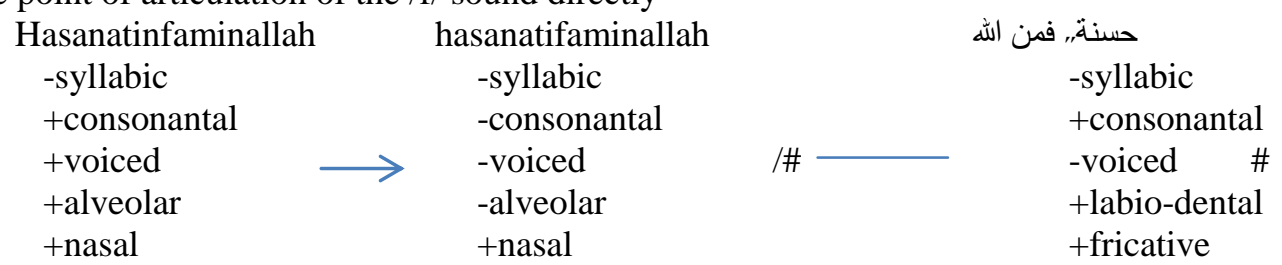

10.Here $/ \mathrm{n} /$ sound is followed by/ت/ sound it is concealed with light nasalization to move to the point of articulation of the sound $/ \mathrm{t} /$ directly
Antum
-syllabic
a tum
+consonantal
-syllabic
+voiced
-consonantal
-voiced
/\#
-syllabic
+consonantal
-voiced \# 


$\begin{array}{lll}\text { +alveolar } & \text {-alveolar } & + \text { alveolar } \\ \text { +nasal } & \text { +nasal } & + \text { plosive }\end{array}$

11.Here / $\mathrm{n} /$ is followed by / ș/ sound it is concealed with light nasalization to move directly to the point of articulation of the sound $/ \mathrm{s} /$

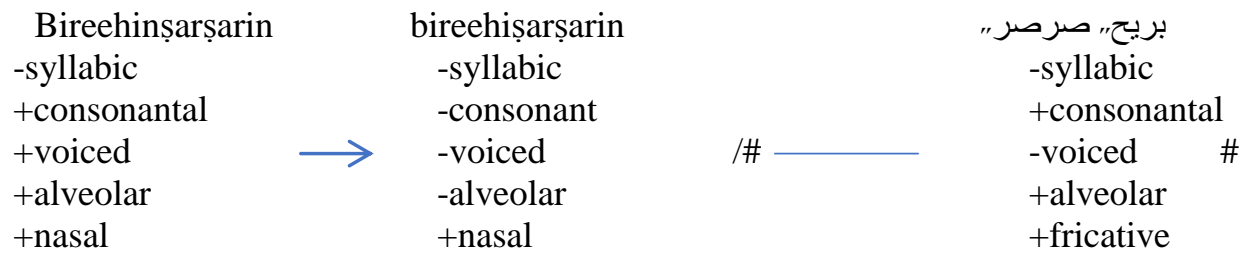

12.Here $/ \mathrm{n} /$ is followed by/di $/$ it is concealed with light nasalization to move to the point of articulation of the sound /ḍ/ directly

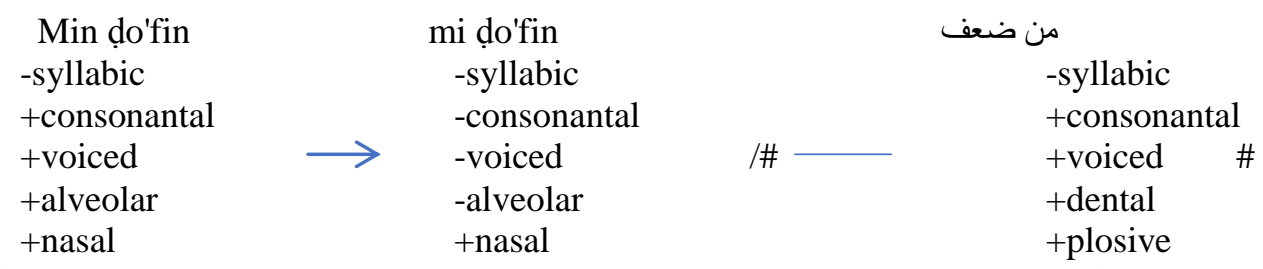

13.Here $/ \mathrm{n} /$ is followed by $/ \mathrm{t} /$ it is concealed with light nasalization to move to the point of articulation of/ț/ directly

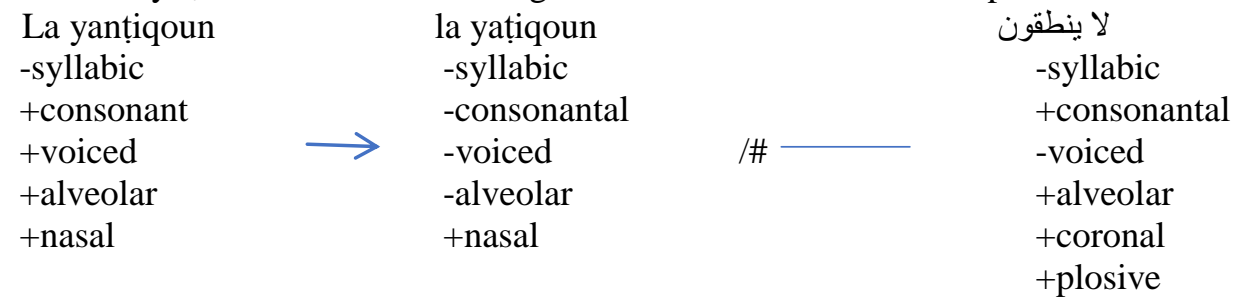

14.here $/ \mathrm{n} /$ sound is followed by /ð/ sound it is concealed with light nasalization to move to the point of articulation of the sound/ð/ directly

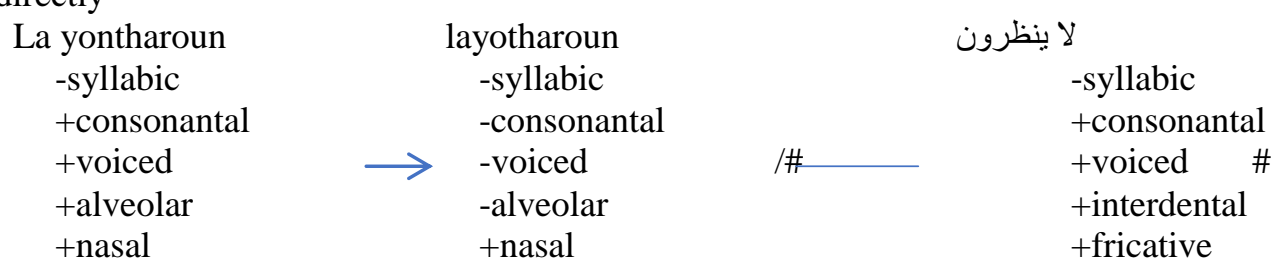

15.here $/ \mathrm{n} /$ sound is followed by /dz/sound it is concealed with light nasalization to move to the point of articulation of the sound /dy/ directly

$\begin{array}{ll}\text { Andza'aho } & \text { adza'aho } \\ \text {-syllabic } & \text {-syllabic } \\ \text { +consonantal } & \text {-consonantal } \\ \text { +voiced } & \text {-voiced } \\ \text { +alveolar } & \text {-alveolar } \\ \text { +nasal } & \text { +nasal }\end{array}$

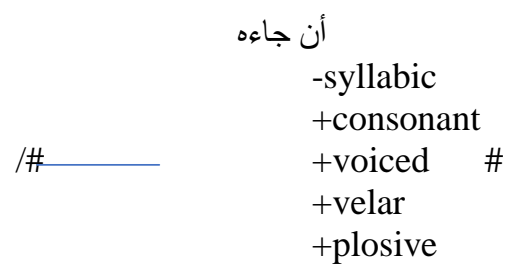

The fourth rule

Clear or obvious (Ithhar):Pronouncing each sound from its point of articulation without any insertion with the other

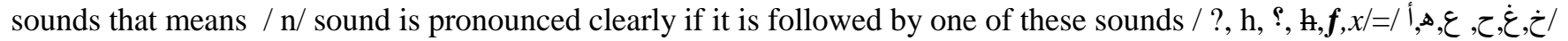
.If one of these six sounds follows a noon sakinah or tanween, in one word or even between two words the noon is then said clearly

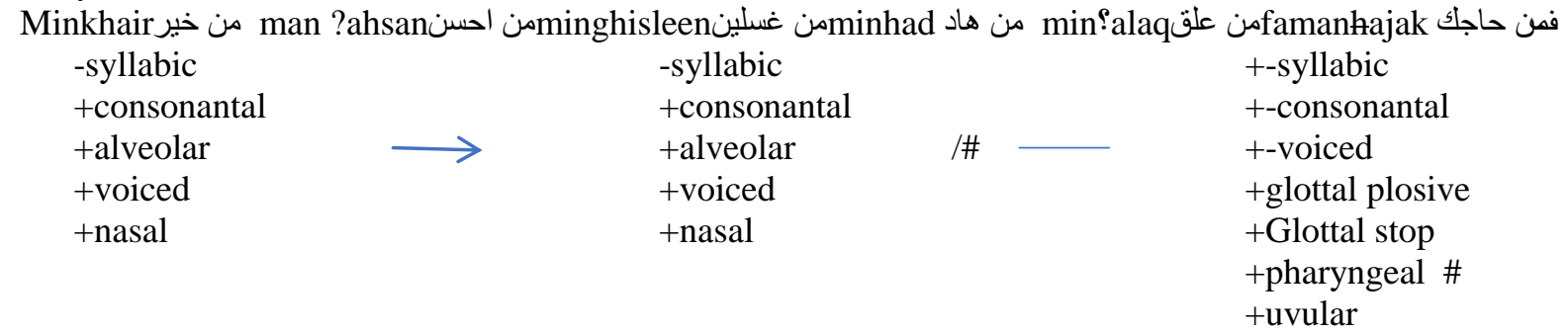


.There is no change of the / $\mathrm{n} /$ sound in these cases.

+ fricative

+approximant

+velar

\section{Conclusion}

The present paper aimed to apply generative phonological rules to the Qur;anic phonological rules focuses on noon sakinah rules and tanween in this regard the researcher has introduced briefly the Qur'anic phonology and the generative phonology theory. The main point that this paper is concluded that the concealment (Ikhfa'a) is neither assimilation nor complete change and easier than clearness all of them at the same time and the tongue moves directly from the point of articulation of the $/ \mathrm{n} /$ to the point of articulation of the third sound directly but with nasalization and with hanging of the body of the tongue for two (harakat) lengthen. The researcher suggests that in this case the generative phonology rules may be applied ,but partially. This paper concludes also that the generative phonological rules can apply to the Qur'anic phonological rules but with the phonetic representation too ,to be compound features that to suit the changes in the sounds features in some cases due to the complex nature of the Qur'anic phonological rules and sounds ' structures.

\section{References}

Abalkheel, Albatol Mohammed,(2016) the behavior of Noon Sakinah and Nunation in Quranic Recitation. International Journal of linguistics

Alduais, Ahmed Mohammed(2012).Qur'anic Phonology and Generative phonology

Formulating Generative Phonological rules to Non syllabic Nuun's rules of the Qur'anic.International Journal of linguistics.

Alfozan ,Abdulrahman Ibrahim(1989)Assimilation in Classical Arabic

Al-Hashmi-Shadiya Adam(2001),The phonology of nasal $n$ in the language of the holy Qur'an M.A thesis. University of Victoria

Alotaibi, yousefand Ali Meftah(2013)Review of distinctive phonetic features and the Arabic share in related modern research. Turkish Journal of Electronical Engineering and computer sciences

Czerepinski Kareema Carol(2000)Tajweed Rules of the Qur'an

Dr.Ayman RushdiSwayd.youtube / retrieved March 2018/

Gold smith, John A(1995)Phonological theory in John A.Gold smith the hand book of phonological theory Blackwell Handbook. Via Goggle Wikipedia./retrieved March 2018retrived on 9/4/2018

Glossary of linguistic Terms http:glossary.sil.org/term/generative phonology retrieved on 2 March 2018

Google.jo.books retrieved March2018march2018

John gold smith and Bernand Laks Generative phonology its origins, its principles and its successors

Katamba, Francis,(1989)An Introduction to phonology

Kenstowicz, Michael J.(1994)Phonology in generative grammar/Michael Kentowicz

Kentowicz, Michael and Kisseberth(1977), Charles topics in phonological theory

Noam Chomsky and Morris Halle,(1968)The sound pattern of Englishwww. Tajweed rules .

www.ewaytoquran.tk.



1القران الكريم2تمهيد في علم التجويد تحقيق د.علي حسين البو اب في كتاب ابن الجزري العرية

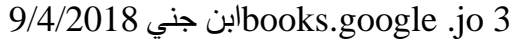

4احكام التجويد/ جوجل/يوتيوب 